Maria Maślanka-Soro ๑ http://orcid.org/0000-0002-0230-3836

Uniwersytet Jagielloński, Kraków

maria.maslanka-soro@uj.edu.pl

\title{
Sztuka Boga i jej metapoetycki charakter w Boskiej Komedii Dantego
}

\section{Abstract \\ God's Art and Its Meta-Poetic Character in Dante's Divine Comedy}

In this study, Maria Maślanka-Soro discusses the problem of meta-poetic themes in the Divine Comedy, focusing in particular on Dante's message about his own work in connection with the topos of Deus Artifex popular in the Middle Ages. The aim is to read this message, referring to the relationship between word and image, in the context of the impression caused by the sight of rock reliefs on the terrace of the proud in the Purgatorio, where the poet, presenting and imitating the art of God, in fact shows the mastery of his own art. In other words, Dante suggests an analogy between the reliefs carved with the "hand" of God, which are vibrant with life and meaningfully called visibile parlare ("visible speech"), and the earthly and extra-terrestrial reality presented in the Divine Comedy with equally great power of expression. The relationship between God's art and Dante's art is presented as part of a more general reflection on the analogy that exists between nature, which is the expression of divine art, and the artistic creation of man. This analogy is based on a similar modus operandi, that is giving the matter a proper form, both by nature, which imitates the creative power of the Prime Mover, and by the artist. The issues outlined above are analysed in here on the basis of relevant fragments of Dante's poem, especially songs X and XII of Purgatorio and some fragments of Paradiso, where the role of Deus Artifex seems to be particularly emphasised. It should be noted that while there are various analyses 
of songs X and XII of Purgatorio, none of them stops at the meta-poetic function of bas-reliefs on the terrace of the proud.

The paper begins with a brief reminder of the Deus Artifex topos in mediaeval culture and especially in the Divine Comedy, where this metaphor is enriched with an element of God's love for his own work. Then, the different shades of meaning of the concept of arte in the Divine Comedy and the hierarchical relationship between God, nature, and art are briefly discussed. Next, the considerations focus on the concept of arte limited to artistic creativity sensu stricto, which takes place on the terrace of the proud. There, penitents contemplate the examples of humility and pride carved on the walls and on the rock path, which are the perfect work of God-the Artist, a work of miniature size when compared to its macroscopic version, which is the Universe created by him. Further analysis leads to the conclusion that the extremely suggestive depiction of the scenes on reliefs, vibrant with life and involving almost all the senses of the viewer, acquires a meta-poetic character in relation to the analogically "living" and "real" episodes presented by Dante in his great poem. The poet implicitly expresses the view that in the works of every great artist, that is, in his understanding, an artist who derives heavenly inspiration, the distance between art and life is blurred.

Keywords: Dante, Divine Comedy, Deus Artifex, meta-poetry, art, ekphrasis, Ovid, Metamorphoses

W Średniowieczu związek pomiędzy słowem i obrazem jest szczególnie ważny nie tylko w twórczości, którą można określić jako artystyczną sensu lato (w iluminowanych rękopisach, w tzw. Biblia pauperum), ale także na poziomie teologicznym, gdyż wpisuje się w dychotomiczną koncepcję świata. Biblijny Logos (Słowo), inaczej niż w filozofii stoickiej, nie jest czystym pierwiastkiem racjonalnym, lecz, by posłużyć się „definicją” Dantego o neoplatońskim rodowodzie, „Światłem intelektualnym pełnym miłości”. Dał on początek dziełu stworzenia, rzeczywistości widzialnej, będącej niedoskonałym

1 „Luce intellettüal piena d'amore” (Par. XXX 40), przeł. M.M.-S. Wszystkie cytaty z Boskiej Komedii w oryginale pochodzą z wydania: Dante Alighieri, La Commedia, vol. 1-3 (Inferno, Purgatorio, Paradiso), con il commento di R. Hollander, trad. a cura di S. Marchesi, Firenze 2011. Cytaty z Boskiej Komedii w przekładzie - 
odbiciem (imago) rzeczywistości nadprzyrodzonej ${ }^{2}$. Istnieje zatem głęboka więź pomiędzy światem i Stwórcą, który jawi się jako Artysta - Deus Artifex ${ }^{3}$. W epoce Dantego ilustrują to przekonanie różne metafory, z których jedna szybko stała się znanym toposem. Wywodzi się ona od mistyka Hugona ze św. Wiktora i przedstawia świat jako księgę zapisaną Bożym palcem, w której literami są poszczególne stworzenia, a w każdym z nich ujawnia się mądrość Stwórcy obecna w świecie niewidzialnym ${ }^{4}$. Ta metafora pojawia się też kilkakrotnie w Komedii (używam tytułu oryginalnie nadanego przez Dantego $)^{5}$, zwłaszcza w ostatniej pieśni Raju, gdzie w jednej z końcowych wizji protagonista postrzega wszechświat jako wielką księgę, a tym, co łączy jej karty, czyli wszystkie byty, jest Boża miłość do stworzenia ${ }^{6}$ :

o ile nie zaznaczono inaczej - pochodzą z wydania: Dante Alighieri, Boska Komedia, przeł. E. Porębowicz, oprac. M. Maślanka-Soro, Kraków 2009.

${ }^{2}$ Już Platon w Timajosie uważał, że Demiurg stworzył świat na podobieństwo rzeczy wiecznych (Tim. 50 C). Korzystam z wydania Plato, Timaeus, Critias, Cleitophon, Menexenus, Epistles, Greek with trans. by R.G. Bury (Loeb Classical Library 234), Cambridge (Mass.) 1989.

${ }^{3} \mathrm{Na}$ temat tego toposu zob. E.R. Curtius, Literatura europejska i łacińskie średniowiecze, przeł. i oprac. A. Borowski, Kraków 1997, s. 576-578.

${ }^{4}$ Zob. Hugo de s. Victore, Eruditionis didascalicae liber septimus, w: idem, Opera omnia, t. 2 (Patrologiae Cursus Completus. Series Latina, ed. J.-P. Migne, t. 176), Parisiis 1854, 814: „Universus enim mundus iste sensibilis quasi quidam liber est scriptus digito Dei, hoc est virtute divina creatus, et singulae creaturae quasi figurae quaedam sunt non humano placito inventae sed divino arbitrio institutae ad manifestandam invisibilium Dei sapientiam".

${ }^{5}$ Zob. Dante, Par. XVII 37-42; XXVI 16-18; XXXIII 85-87.

${ }^{6}$ Bóg przedstawia się tu nie tylko jako Ten, od którego wywodzi się i do którego powraca wszelkie stworzenie, ale również jako wszechwiedzący Umysł. W myśli zawartej w tych wersach niektórzy krytycy doszukują się wymowy metapoetyckiej: można je odnieść nie tylko do Stwórcy Wszechświata, lecz również do twórcy poematu, czyli volume, zawierającego na swoich kartach (fogli) całą rzeczywistość (zob. G. Güntert, Canto XXXIII, w: Lectura Dantis Turicensis, a cura di G. Güntert, M. Picone, vol. 3: Paradiso, Firenze 2002, s. 510). Wymiar metapoetycki miało też wcześniejsze porównanie (Par. XXXIII 65-66), w którym ulotność rajskich wizji w pamięci Dantego autora znajdowała analogię w rozpraszaniu się pod wpływem 
Nel suo profondo vidi che s'interna, legato con amore in un volume, ciò che per l'universo si squaderna: sustanze e accidenti e lor costume quasi conflati insieme, per tal modo che ciò ch'i' dico è un semplice lume. La forma universal di questo nodo credo ch'i' vidi, perché più di largo, dicendo questo, mi sento ch'i' godo. (Par. XXXIII 85-93)

[W głębi boskiego Umysłu zobaczyłem, jak miłość łączy w księgę to, co we wszechświecie ukazuje się na osobnych kartach: zarówno byty skończone [substantiae], jak ich przymioty [accidentes] oraz wzajemne relacje [habitus], idealnie połączone: sposób, w jaki o tym mówię, jest tylko nikłym odblaskiem owej wizji. Jestem przekonany, że zobaczyłem wówczas istotę wszechświata [jego uniwersalną formę], ponieważ gdy o tym mówię, odczuwam coraz większą szczęśliwość]. (przeł. M.M.-S.)

W innym miejscu Dante nazywa wprost Boga Stwórcę mistrzem, który w miłosnym zachwyceniu nie może oderwać oczu od owoców własnej sztuki:

Leva dunque, lettore, a l'alte rote meco la vista, dritto a quella parte dove l'un moto a l'altro si percuote; e lì comincia a vagheggiar ne l'a r te di quel maestro che dentro a sé l'ama $\mathrm{m}^{7}$

podmuchów wiatru przepowiedni Sybilli Kumańskiej zapisanych na liściach (foglie); jednak, jak często u Dantego, porównanie to jest pozorne i wskazuje implicite na kontrast z opisaną przez Wergiliusza (Aen. III 441-452) sytuacją: w odróżnieniu od Sybilli on może przekazać choćby część swoich wizji dzięki łasce otrzymanej od Boga: karty jego poematu są, podobnie jak karty księgi świata, połączone Bożą miłością; na temat tego porównania zob. P. Boitani, The Sibyl's Leaves. A Study of “Paradiso” XXXIII, „Dante Studies” 96 (1978), s. 83-126; R. Hollander, Il Virgilio dantesco: tragedia nella "Commedia", Firenze 1983, s. 145-154.

7 O ile u Platona Demiurg też stworzył świat (jednak nie z niczego, ale z odwiecznej materii) na swoje podobieństwo (Tim. 39 D-E; 48 E) i można go określić - 
tanto che mai da lei l'occhio non parte.

(Par. X 7-12)

[Podnieś więc oczy ze mną, czytelniku.

Tam, gdzie niebiosa w taniec myśl porywa,

tam, gdzie zobaczysz zodiak na równiku,

i w zachwyceniu patrz na wielkie dziwa [sztukę]

owego mistrza, co je kocha tyle,

że od nich oka swego nie odrywa] ${ }^{9}$.

Alan z Lille w zwięzłej formule mnemotechnicznej pośrednio nawiązuje do koncepcji Deus Artifex, streszczając istotę symbolizmu średniowiecznego: „Omnis mundi creatura / quasi liber et pictura / nobis est, et speculum"10. Nie tylko natura jest pełna symboli, res będących signa, które odsyłają do rzeczywistości duchowej, ale także niektóre ludzkie dzieła, zwłaszcza te będące owocem ars i ingenium ${ }^{11}$. Takim na pewno jest Komedia: ma ona otworzyć czytelnika na prawdy niedostępne dla intelektu, będąc z założenia poematem natchnionym (taka konwencja wielokrotnie przewija się na jej kartach) ${ }^{12}$ i nośnikiem głębszych znaczeń.

w kategoriach prawdopodobieństwa - jako mimema paradeigmatos (Tim. 50 C), myśleniu greckiemu, zakorzenionemu w intelektualizmie etycznym (zob. G. Reale, Storia della filosofia antica, vol. 5, Milano 1989, s. 144-145), obca jest jednak refleksja, że mógł to uczynić z miłości.

${ }^{8} \mathrm{O}$ ile nie zaznaczono inaczej, wszystkie wyróżnienia w cytatach pochodzą ode mnie.

${ }^{9}$ Dante Alighieri, Raj. Boskiej komedii część trzecia, przeł. A. Kuciak, Poznań 2004; dalej przekład oznaczany jako: przeł. A.K.

10 "Całe stworzenie świata / jest dla nas niejako / księgą, obrazem i zwierciadłem", cyt. za: E.R. Curtius, Literatura europejska..., s. 326.

${ }^{11}$ Według Horacego (Ars poetica 408-411) cechują one doskonałe dzieła.

12 Zob. na przykład Par. X 27; XXV 1-2; aluzje do charakteru natchnionego i profetycznego Boskiej Komedii są szczególnie obecne w końcowych pieśniach Czyśćca, których akcja toczy się w Raju Ziemskim (Paradiso Terrestre), jak również w centralnych pieśniach Raju (XV-XVII), podczas rozmowy Dantego pielgrzyma z duchem jego przodka Cacciaguidy. Na ten temat istnieje obszerna bibliografia, zob. zwłaszcza: B. Nardi, Dante profeta, w: idem, Dante e la cultura medievale, nuova 
Dante odsłania przed odbiorcą swojego dzieła rzeczywistość zaświatów, świat ducha wyzwolonego z więzów materii (w Raju) lub dopiero się z niej uwalniającego (w Czyśćcu) albo też przygniecionego jej ciężarem na zawsze (w Piekle). Realizuje się tam dzieło Bożej sprawiedliwości zgodnie z przekonaniem, że „na tym świecie jest czas na miłosierdzie, na tamtym zaś jedynie na sprawiedliwość” („in isto mundo est tempus misericordie, in alio, autem, est solum tempus iustitie") ${ }^{13}$. Unaocznia to Dantemu pielgrzymowi napis na bramie Piekła: „Jam dzieło wielkiej, sprawiedliwej ręki” („Giustizia mosse il mio alto fattore"; Inf. III 4). Trochę dalej, na widok bluźnierców w siódmym kręgu, sieczonych ognistym deszczem (kara ta, wspólna też dla sodomitów i lichwiarzy, czyli tych, którzy zgrzeszyli przeciwko Bogu, naturze i sztuce, nawiązuje do tej, jaka spotkała mieszkańców biblijnej Sodomy i Gomory), narrator komentuje: „Widać, jak się spełnia budząca przerażenie sztuka sprawiedliwości”" („Si vede di giustizia orribil a rte"; Inf. XIV 6). W Piekle kara jest narzędziem sprawiedliwości Boga i zarazem jej dziełem (tak należy tu rozumieć pojęcie $a r t e)^{15}$, gdyż pociąga za sobą mniej lub bardziej przerażające przemiany in malum różnych kategorii potępionych, zwłaszcza tych z ostatnich kręgów: są one konsekwencją utraty w różnym stopniu

ed. a cura di P. Mazzantini, introduzione T. Gregory, Roma-Bari 1983, s. 265-326; Z.G. Barański, Notes on the Genesis of Dante's "Commedia". "'l poema sacro [...] che m'ha fatto per molti anni macro", „Italiana” 9 (2000), s. 58-81; A.A. Iannucci, Dante: poeta o profeta?, w: "Per correr miglior acque...". Bilanci e prospettive degli studi danteschi alle soglie del nuovo millennio. Atti del Convegno di Verona-Ravenna (25-29 ottobre 1999), vol. 1, Roma 2001, s. 93-114; R. Osculati, La profezia nel pensiero di Dante, w: Il pensiero filosofico e teologico di Dante Alighieri, a cura di A. Ghisalberti, Milano 2001, s. 39-57; A. Placella, "Vidi cose che ridire / né sa né può chi di là sù discende». Dante poeta-teologo e il modello paolino di visione e profezia, „Critica letteraria” 45 (2017), no 4, s. 641-666; eadem, Profetismo e archetipo del 'puer' in Dante tra Isaia, Virgilio e Paolo, Roma 2017.

${ }_{13}$ Zob. Guido da Pisa, Expositiones et Glose super Comediam Dantis, ed. by V. Cioffari, Albany (N.Y.) 1974, s. 383.

14 Przeł. M.M.-S.

15 Zob. Dante Alighieri, Inferno, revisione del testo e commento di G. Inglese, Roma 2007, komentarz do Inf. XIV 6, s. 168. 
człowieczeństwa, efektem irracjonalnego zezwierzęcenia („matta bestialitate"; Inf. XI 82-83), a z perspektywy intertekstualnej można je odczytać nierzadko jako parodie przemian z Metamorfoz Owidiusza. Dante ukazuje, jakiej degradacji może ulec człowiek, a właściwie racjonalna część jego duszy (bo jedynie ta przetrwała na wieczność), pozbawiona iskry Bożego światła i miłości ${ }^{16}$, które za życia chroniły jego status imago Dei, czyli autentycznego dzieła szt uki Boga artysty, o ile sam człowiek nie nadużył wolnej woli (liberum arbitrium).

Gdy Wergiliusz wykłada Dantemu w pieśni XI Piekła strukturę tej części zaświatów, inspirowaną częściowo ogólnym podziałem złych skłonności u Arystotelesa w Etyce nikomachejskiej ${ }^{17}$, wyjaśniając winę lichwiarzy, którzy zgrzeszyli przeciwko sztuce (arte rozumianej jako odpowiednik rzymskiej ars, czyli twórczego działania opartego na określonych regułach $)^{18}$, ustanawia w swoim wywodzie interesującą hierarchię pomiędzy Bogiem, naturą i sztuką:

«Filosofia», mi disse, «a chi la 'ntende, nota, non pure in una sola parte, come natura lo suo corso prende dal divino 'ntelletto e da sua arte; e se tu ben la tua Fisica note, tu troverai, non dopo molte carte, che l'arte vostra quella, quanto pote, segue, come 'l maestro fa 'l discente; sì che vostrarte a Dio quasi è nepote». (Inf. XI 97-105)

16 Zob. Par. VII 79-80: „Solo il peccato è quel che la disfranca, e falla dissimile al sommo bene, / per che del lume suo poco s’imbianca” („W grzech wpadłszy, rychło wolności ułaknie, / Toż grzech w niej Boże podobieństwo skłóci; / Nie rozjaśnione Bożym światłem - blaknie").

17 Zob. Eth. Nic. VII 1 1145a 15-18.

18 Fernando Salsano tłumaczy tu arte jako „operazione” albo „attività pratica”, powołując się na Tomasza z Akwinu (Ia IIae, q. 57, a. 3, ad 3): „ars nihil aliud est quam ratio recta aliquorum operum faciendorum” („sztuka nie jest niczym innym jak zasadą racjonalną, na której opiera się wykonanie pewnych rzeczy"; przeł. M.M.-S.), F. Salsano, Arte, w: Enciclopedia Dantesca, vol. 5, Milano 2005, s. 612. 
[Rzekł: „Filozofia mówi o tym szczerze

i nie raz temu, co zna jej nauki,

jako natura cała bieg swój bierze

z Bożej mądrości oraz z Bożej sztuki;

i nie po wielu stronach w księgozbiorze

twoja Fizyka powie ci bez luki,

że za naturą sztuka tak, jak może,

tak jak za mistrzem uczeń idzie w ślady,

że wasza sztuka jest jak wnuczę Boże"].

(przeł. A.K.)

W tym fragmencie nat u ra ukazana jest jako emanacja boskiego umysłu i jego sztuki, w nawiązaniu do Arystotelesa ${ }^{19}$ i Tomasza z Akwinu („Omnes res naturales productae sunt ab arte divina”) ${ }^{20}$, a sztuka ludzka jest naśladownictwem natury, lecz nie w znaczeniu mimesis aktu twórczego zgodnego z zasadą prawdopodobieństwa, którego efekt nie dorównuje „modelowi”21 pod względem doskonałości - lecz w sensie modus operandi ${ }^{22}$, polegającego na nadaniu materii odpowiedniej formy, podobnie jak to czyni natura, która naśladuje moc twórczą Pierwszego Poruszyciela. Dostrzeżona analogia pomiędzy naturą i sztuką (czyli sztuką boską i ludzką) podkreśla fakt stwarzania przez obie nowej rzeczywistości. Ta koncepcja była dobrze znana

19 Zob. Metaph. XII 7 1072b.

20 Tomasz z Akwinu, Summa theologiae Ia, q. 91, a. 3, www.corpusthomisticum. org/sth0000.html (dostęp: 2.06.2019) - „Cała przyroda jest tworem boskiej sztuki”; przeł. M.M.-S.; zob. też Dante, Mon. I iii 2: „Deus ecternus arte sua, que natura est” („Wiekuisty Bóg swoją sztuką, która jest naturą”); ibidem II ii 3: „A coelo, quod organum est artis divine, quam 'naturam' comuniter appellant” („Od nieba, które jest narzędziem Bożej sztuki, nazywanej powszechnie naturą”; cytaty oryginalne pochodzą z wydania: Dante Alighieri, Monarchia, introduzione di G. Petrocchi, a cura di M. Pizzica, Milano 1988; przeł. M.M.-S.); zob. też E. De Bruyne, Études d’esthétique médiévale, t. 3, Bruges 1946, s. 317.

${ }^{21}$ Zob. J. Bartuschat, "Non pur Policteto, ma la natura». Perfezione dell'arte e perfezione della natura in Dante e Boccaccio, w: Studi sul canone letterario del Trecento per Michelangelo Picone, a cura di J. Bartuschat, L. Rossi, Ravenna 2003, s. 81.

${ }_{22}$ Zob. Z.G. Barański, Canto XXV, w: Lectura Dantis Turicensis, a cura di G. Güntert, M. Picone, t. 2: Purgatorio, Firenze 2001, s. 394. 
w Średniowieczu, przede wszystkim dzięki komentarzowi Tomasza z Akwinu do fragmentu Fizyki, do którego Alighieri tu nawiązuje ${ }^{23}$. Wergiliusz w swojej krytyce lichwiarzy kładzie nacisk na całkowicie pozbawioną cech autentycznej ars ich godną potępienia „profesję", prowadzącą do bogacenia się na podstawie samego posiadania, któremu nie towarzyszy twórczy wysiłek. Dlatego ich działalność nie jest w żaden sposób zakorzeniona w rzeczywistości transcendentnej, nie zasługuje na miano Bożej „wnuczki”.

W powyższym fragmencie zasugerowana jest też opozycja pomiędzy sztuką Boga, który jest autonomiczny w swoim działaniu, i sztuką człowieka, potrzebującego pośrednictwa natury, by tworzyć ${ }^{24}$. To przeciwstawienie nabiera innego znaczenia w pieśni X Czyśćca, gdzie pojęcie sztuki zostaje zawężone do twórczości artystycznej sensu stricto, w tym wypadku do sztuki figuratywnej. Jednak można ją, jak zobaczymy, odczytać także w kluczu autobiograficznym, świadczącym o wysokiej samoświadomości Dantego jako poety; ważna tu będzie obecna implicite relacja pomiędzy słowem a obrazem, to jest słowem poetyckim Dantego a opisywanymi tam płaskorzeźbami, których twórcą jest sam Bóg ${ }^{25}$.

Akcja wspomnianej pieśni rozgrywa się na pierwszym tarasie Czyśćca, przeznaczonym dla pysznych. Układ tej części zaświatów jest, podobnie jak pozostałych, hierarchiczny: w dolnej części Góry

${ }^{23}$ Zob. Arystoteles, Phys. II 2 194a 22: „Ars imitatur naturam” („Sztuka naśladuje naturę"; przeł. M.M.-S.), Aristotle, Physics, Books 1-4, Greek with trans. by P.H. Wicksteed, F.M. Cornford (Loeb Classical Library 228), Cambridge (Mass.) 1957; Les Auctoritates Aristotelis. Un florilège médiéval. Étude historique et édition critique, éd. par J. Hamesse, Louvain 1974, s. 145: „Ars imitatur naturam in quantum potest” („Sztuka naśladuje naturę w stopniu, w jakim jest to możliwe”; przeł. M.M.-S.).

${ }^{24}$ Opozycja jest też obecna na poziomie stylistycznym: syntagma „sua arte” ma swój (niedoskonały semantycznie) odpowiednik w syntagmie „vostr’arte”.

${ }^{25} \mathrm{Na}$ temat relacji pomiędzy słowem a obrazem w przykładach odnoszących się do cnót i grzechów w Czyśćcu, w powiązaniu z ars memoriae, zob. P. Vescovo, Ecfrasi con spettatore (Dante, "Purgatorio", X-XVII), „Lettere italiane” 45 (1993), no 3 , s. 335-360. 
Czyśćcowej, powyżej Przedczyśćca (Antipurgatorio), jest miejsce czasowego pobytu dla tych, którzy wykazali się szczególnymi skłonnościami do najcięższych grzechów głównych, a pycha, jak wiadomo, zajmuje pośród nich pierwsze miejsce, uznana w Biblii za „początek każdego grzechu” (,initium omnis peccati”; Syr 10,13) ${ }^{26}$. Duchy znoszą karę fizyczną ${ }^{27}$, opartą na zasadzie contrappasso, czyli analogiczną lub antytetyczną w stosunku do popełnionej winy: w Czyśćcu przeważa kryterium per antithesin, ponieważ kara ma wydźwięk terapeutyczny: ma pomóc w przemianie wewnętrznej, w wyjściu ze stadium „poczwarki", na którym człowiek zatrzymał się na ziemi, i w osiągnięciu stanu „rajskiego motyla” („angelica farfalla”; Purg. X 125), dojrzałości duchowej; w Piekle natomiast jest ona najczęściej obrazem winy.

Ponadto duchy pokutujące w Czyśćcu kontemplują obrazy (niekiedy w formie wizji mniej lub bardziej ekstatycznych) lub słuchają różnych głosów ukazujących im exempla cnoty przeciwnej do ich grzechu, jak również te odnoszące się do ukaranej winy. Owe figury przykład owe, jak je określił Ernst Robert Curtius ${ }^{28}$, zaczerpnięte z Biblii i kultury klasycznej, wpisują się w tradycję sięgającą jeszcze czasów wczesnochrześcijańskich $^{29}$, a ich schemat stylistyczny, w którym obok postaci biblijnych występują też antyczne, „Dante rozwinął $\mathrm{z}$ wielkim artyzmem”30.

W pieśniach X i XII pyszni, uginając się pod brzemieniem głazów (contrappasso nawiązujące do kary mitologicznego Atlasa), patrzą na umieszczone na ścianach tarasu w jego dolnej części płaskorzeźby z przykładami pokory i znajdujące się na posadzce sceny ilustrujące ukaraną pychę ${ }^{31}$. Jedne i drugie są doskonałym dziełem Boga-Artysty,

26 Zob. też Tomasz z Akwinu, Summa theologiae IIa-IIae, q. 162, a. 7.

${ }^{27}$ Jest to pozorny paradoks: każdy duch posiada tak zwane ciało eteryczne (corpo aereo), przez co odczuwa cierpienia fizyczne, głód, gorąco, zimno itd.: koncepcja ta jest wyłożona przez ducha poety Stacjusza w Purg. XXV.

28 Zob. E.R. Curtius, Literatura europejska..., s. 372-375.

29 Ibidem, s. 372.

${ }^{30}$ Ibidem, s. 374. Na temat kunsztownego układu przykładów w Purg. XII zob. M. Maślanka-Soro, Antyczna tradycja epicka u Dantego, Kraków 2015, s. 357-358.

31 Takie rozplanowanie przykładów pozytywnych i negatywnych nie jest przypadkowe: te ostatnie są deptane przez duchy pysznych, co jest wyrazem ich dystansowania 
dziełem o wymiarze miniaturowym wobec jego makroskopijnej wersji, jaką jest stworzony przez Niego Wszechświat. Czytelnik, zachowując jeszcze w pamięci niezwykle sugestywnie i plastycznie opisane lub wręcz przedstawione ( $w$ mimetycznych scenkach-obrazach) męki piekielne o wykładni symbolicznej, które w swojej wyobraźni chłonął za pomocą wszystkich niemal zmysłów: wzroku, słuchu, węchu i dotyku, otrzymuje sygnał metapoetycki sugerujący analogię pomiędzy płaskorzeźbami, wymownie nazwanymi „,visibile parlare” („dającą się zobaczyć mową"; Purg. X 95), i rzeczywistością pozaziemską (ale też ziemską, do której są bardzo liczne odwołania), przedstawioną w Komedii z wielką siłą ekspresji, przy pomocy działających na wyobraźnię malarskich metafor czy udramatyzowanych, często podwójnych porównań oraz innych środków ekspresji. Dotyczy to zarówno epizodów rozwijających się wokół poszczególnych postaci spotkanych przez Dantego pielgrzyma, jak i opowiadanych przez nie historii, opisów przestrzeni itd. ${ }^{32}$ Innymi słowy to, co ukazuje Dante autor w całym swoim poemacie, oraz sposób, w jaki to czyni (owo „visibile parlare” właśnie), miałyby miniaturowy odpowiednik w dziełach boskiej sztuki na tarasie pysznych. Można tu zatem mówić o tak zwanej mise en abyme, specyficznej technice polegającej na mimetycznym nawiązywaniu dzieła do siebie samego ${ }^{33}$.

W pieśniach X i XII nie tylko sporo miejsca poświęca się sztuce (przede wszystkim oddziałującym na wszystkie zmysły opisom owych

się wobec własnej winy. Opozycja pomiędzy układem wertykalnym i horyzontalnym może być interpretowana symbolicznie jako ilustracja zapowiedzi Chrystusa, że kto się wywyższa, będzie poniżony, a kto się poniża, będzie wywyższony (zob. Łk 14,11).

32 Jeden z krytyków nazwał Boską Komedię „największą i najpiękniejszą sumą porównań i przykładów w średniowiecznej literaturze europejskiej”; przeł. M.M.-S. („la più grande e la più bella somma di similitudini ed esempi della letteratura medievale europea"), C. Delcorno, Dante e l'«Exemplum» medievale, „Lettere italiane" 35 (1983), no 1, s. 4-5.

${ }^{33}$ Nie jest to jedyny przykład mise en abyme w Boskiej Komedii: inny można odnaleźć w Inf. V, gdzie figura, jaką Minos naznacza na własnym ciele za pomocą spiralnie skręconych zwojów swojego ogona, którym wyznacza każdemu potępionemu miejsce w odpowiednim kręgu, symbolizuje spiralną strukturę Piekła i zarazem iter Dantego pielgrzyma. 
artefaktów), ale pojawia się też minirefleksja teoretyczna na temat mimesis. Niedoścignione piękno płaskorzeźb, ale przede wszystkim emanujące z nich życie mogłoby zawstydzić, jak wyjaśnia narrator, nie tylko największych artystów wszystkich czasów (reprezentowanych tu przez Polikleta), ale wręcz samą naturę:

[...] marmo candido e addorno

d'intagli sì, che non pur Policleto, ma la natura lì avrebbe scorno.

(Purg. X 31-33)

[[...] białymi błyszczały marmury,

Pokryte rzeźbą, co nie w Poliklecie,

Lecz by zbudziła zazdrość ${ }^{34} \mathrm{u}$ natury].

Powyższa myśl, wywołana widokiem „obrazów tylu przykładów pokory” („imagini di tante umilitadi”; w. 98) ${ }^{35}$, pośrednio może dotyczyć poezji Dantego, zdolnej przedstawić nawet sztukę samego Boga. Ponadto pozorny paradoks tkwiący w tej tercynie odwraca sens sztuki jako iluzji, wywodzący się z poglądów Platona. Marmurowe dzieła Boga artysty, nadzwyczaj żywe oraz „prawdziwe” („verace”36; Purg. X 37) - i dlatego właśnie określone jako „dająca się zobaczyć

${ }^{34} \mathrm{~W}$ oryginale chodzi raczej o zawstydzenie niż zazdrość.

${ }^{35}$ Dante podkreśla przyjemność czysto estetyczną, jaką w nim wywołuje oglądanie tych reliefów (których cel dydaktyczny nie ulega żadnej wątpliwości): „Mentr'io mi dilettava di guardare / l'imagini di tante umilitadi” („Podczas gdy patrzyłem z wielką przyjemnością na obrazy tylu przykładów pokory”; w. 97-98). Robert Hollander w swoim komentarzu do Purg. X 31-33 zwraca uwagę na estetyczne spojrzenie Dantego na sztukę także w porównaniu pod koniec tej pieśni (w. 131134): kamienna figura uginająca się i skulona pod ciężarem kapitelu (czy innego elementu architektonicznego) może w nas wywołać autentyczne uczucie bolesnego współczucia (zob. Dante Alighieri, La Commedia, t. 2: Purgatorio, s. 84).

${ }^{36}$ Epitet verace odnosi się w Komedii do tego, co absolutnie prawdziwe, w szczególności do rzeczywistości rajskiej: zob. Par. XXXI 107: „Dio verace” („prawdziwy Bóg”); Purg. XVIII 22: „esser verace” („prawdziwy byt”); Par. XXX 98: „regno verace” („prawdziwe królestwo”); Purg. XXX 7: „gente verace” („prawdziwi ludzie”): chodzi o 24 starców (Purg. XXIX 83) wchodzących w skład symbolicznego orszaku 
mowa” („visibile parlare”), stanowią dalej (w pieśni XII) przedmiot jeszcze większego zachwytu narratora, połączonego wręcz z uniesieniem, jakie przebija $\mathrm{z}$ silnie emotywnie nacechowanego pytania retorycznego, zamykającego „przegląd” skalnych obrazów:

Qual di pennel fu maestro o di stile che ritraesse l'ombre e' tratti ch'ivi mirar farieno uno ingegno sottile? Morti li morti e i vivi parean vivi: non vide mei di me chi vide il vero, quant'io calcai, fin che chinato givi.

(Purg. XII 64-69)

[Któryż artysta w pędzlu albo dłucie Tak oddał kształty i ruchy, że niemi Podziw się wrażał w patrzącego czucie?

Żyw zdał się żywym, a martwi martwemi;

Nie widział lepiej, kto by widział jawę,

Niż ja, tam idąc z oczyma ku ziemi].

Zobaczmy, jak Dante poeta naśladuje sztukę Boga i że nie chodzi tu jedynie o „malowanie” słowami, o ukłon w stronę Horacjańskiej zasady: „ut pictura poesis”, a tym bardziej o hołdowanie (zapewne nieznanej Dantemu) Symonidesowej myśli: „poezja jest mówiącym malarstwem” (bo tu także obrazy boskie „przemawiają”), ale o zatarcie dystansu pomiędzy sztuką i życiem, pomiędzy tym, „co jest”, a tym, „co wydaje się być” ${ }^{37}$. Pokazuje to na przykład ekfraza ${ }^{38}$ odnosząca

w Edenie, którzy u Dantego, pod wpływem Apokalipsy św. Jana $(4,4)$, symbolizują 24 księgi Starego Testamentu.

37 Zob. T. Barolini, Ricreare la creazione divina: l'arte aracnea nella cornice dei superbi, w: eadem, La "Commedia" senza Dio. Dante e la creazione di una realtà virtuale, trad. it. R. Antognini, Milano 2003, s. 180.

${ }^{38}$ Według retoryki aleksandryjskiej ekfraza to opis, którego przedmiot zostaje w całej pełni ukazany oczom tego, kto go ogląda (zob. G. Güntert, Canto X, w: Lectura Dantis..., vol. 2: Purgatorio, s. 148). U Dantego patrzący (Dante i Wergiliusz) są wpisani w tekst Komedii, w którym przedstawia się ich stopień 
się do sceny ze Starego Testamentu ilustrującej pokorę króla Dawida, który nie wahał się zatańczyć wraz z całym ludem przed Arką Przymierza, wprowadzaną właśnie do Jerozolimy (2 Sm 6,12-23):

Era intagliato lì nel marmo stesso

lo carro e ' buoi, traendo l'arca santa,

[...]

Dinanzi parea gente; e tutta quanta,

partita in sette cori, a' due mie' sensi

faceva dir, l'un "No", l'altro "Sì, canta".

Similemente al fummo de li 'ncensi

che v'era imaginato, li occhi e'l naso

e al sì e al no discordi sensi.

Lì precedeva al benedetto vaso,

trescando alzato, l'umile salmista ${ }^{39}$,

e più e men che re era in quel caso $^{40}$.

(Purg. X 55-56; 58-66)

zaangażowania w oglądane sceny, a nawet są oni „obecni” w obrębie samych ekfraz (np. drugiej i trzeciej); zob. L. Faedo, L'impronta delle parole. Due momenti della pittura di ricostruzione, w: Memoria dellantico nellarte italiana, vol. 2, a cura di S. Settis, Torino 1985, s. 3-42. Ekfraza może odnosić się nie tylko do rzeczywistego dzieła sztuki, lecz również do fikcyjnego. John Hollander czyni rozróżnienie pomiędzy ekfrazą pojęciową, typową dla tradycji klasycznej, która polega na opisie wyobrażonego przedmiotu, a ekfrazą mimetyczną, odnoszącą się do dzieł istniejących (J. Hollander, The Gazer's Spirit. Poems Speaking to Silent Works of Art, Chicago 1995, s. 3 i nn.).

${ }^{39}$ Dawid jako „pokorny psalmista” jest figurą Dantego, zob. T. Barolini, Dante's Poets. Textuality and Truth in the "Comedy", Princeton (N.Y.) 1984, s. 275-278; R. Hollander, komentarz do Purg. X 65, w: Dante Alighieri, La Commedia, vol. 2: Purgatorio, s. 86: „Dante è un «umile salmista», la controparte moderna di David”; zob. też G. Ledda, La danza e il canto dell' «umile salmista»: David nella "Commedia" di Dante, w: Les figures de David à la Renaissance, éd. par E. Boillet, S. Cavicchioli, P.-A. Mellet, Genève 2015, s. 225-246.

${ }^{40}$ Dawid był „bardziej” królem ze względu na swoją pokorę, która go wywyższała w oczach Boga, natomiast w oczach ludzi pysznych (jak patrząca na niego z pogardą żona Mikol) przyjął postawę niegodną króla (był „mniej” królem); zob. też nieco inne wyjaśnienie w: G. Güntert, Canto X, w: Lectura Dantis..., vol. 2: Purgatorio, s. 148. 
[Były wycięte w marmurze wóz i woły ciągnące świętą Arkę [...]. A przed nią tłum ludzi i wszyscy razem, podzieleni na siedem chórów, słali sprzeczne sygnały obu moim zmysłom:jeden (słuch)mi mówił: "Nie, nie śpiewają", a drugi (wzrok): „Tak, śpiewają”. Podobnie skłócone były ze sobą moje oczy i nos na widok unoszącego się dymu z kadzideł. A przed błogosławioną Arką postępował, tańcząc $\mathrm{z}$ uniesioną szatą, pokorny psalmista, który w tym momencie wydawał się zarazem bardziej i mniej królem]. (przeł. M.M.-S.)

Narrator, komentując ten i pozostałe reliefy ilustrujące pokorę (pierwszy przedstawiał scenę Zwiastowania z jej krótką, „widoczną” wymianą zdań pomiędzy Maryją i archaniołem Gabrielem, obrazującą tajemnicę Słowa, które staje się Ciałem dla zbawienia ludzkości ${ }^{41}$, a trzeci - ożywiony dialog pomiędzy cesarzem Trajanem i biedną wdową, która skłania go wobec całego wojska, by opóźnił wyprawę wojenną i wymierzył jej sprawiedliwość) ${ }^{42}$, nazywa autora rzeźb „Tym, dla którego żadna rzecz nie jest nowa” („Colui che mai non vide cosa nova”; w. 94), podkreślając zarazem, że to „visibile parlare” jest dla nas czymś nowym, bo tu na ziemi się go nie spotyka („novello a noi, perché qui non si trova”; w. 96). W pierwszym stwierdzeniu mamy potwierdzenie myśli średniowiecznej, że na świecie nie istnieje nic, co by najpierw nie powstało w Umyśle Boga. Co natomiast stanowiłoby novum dystansujące sztukę ludzką od boskiej? Ekfrazy

${ }^{41}$ Zob. Purg. X 34-45, zwłaszcza 43-45: „E avea in atto impressa esta favella / 'Ecce ancilla Deï, propriamente / come figura in cera si suggella” („W geście jej skromnym odbiły się słowa: / 'Otom ja Twoja służebnica, Panie!' - / Jakby je pieczęć odbiła woskowa").

${ }^{42}$ Legenda ta wywodzi się prawdopodobnie $\mathrm{z}$ anegdoty u Kasjusza Diona, następnie pojawia się w Vita S. Gregorii Magni Pawła Orozjusza i wielu późniejszych tekstach (w Złotej legendzie Jacopa da Varazze, Speculum historiale Vincenta de Beauvais i niektórych toskańskich volgarizzamenti). Dante mógł czerpać inspirację z dzieła Jana z Salisbury Policraticus (V 8), w którym dialog pomiędzy wdową a Trajanem ma bardzo podobne zakończenie; zob. komentarz w: Dante Alighieri, Commedia, a cura di A.E. Quaglio, E. Pasquini, t. 2: Purgatorio, Milano 2010 ${ }^{14}$, s. 181; zob. też E.R. Curtius, Literatura europejska..., s. 375; G. Güntert, Canto X, w: Lectura Dantis..., vol. 2: Purgatorio, s. 149. 
nie pozostawiają wątpliwości co do tego, że pierwsza unieruchamia życie, utrwalając tylko jakiś jego moment, a druga, dzięki sile iluzji prowadzącej do „kłótni” zmysłów, tchnie w obraz życie z wszystkimi jego przejawami w czasie i przestrzeni. W zacytowanej powyżej scenie do uszu nie dochodzi żaden dźwięk, ale jest on uchwytny dla oczu, które cieszą się też widokiem dymiącego kadzidła, „czując” jego iluzoryczną woń, podczas gdy nos zdaje się temu zaprzeczać. Z kolei w dłuższej i bardziej skomplikowanej scenie następnej czytelnik (który zna legendę o Trajanie i wdowie, popularną w Średniowieczu), patrząc na relief, jest skłonny wyobrazić sobie ich dialog (przez Dantego istotnie przytoczony) w otoczeniu rzymskich proporców z orłami powiewających na wietrze.

Mamy tu do czynienia (a podobnie w przykładach ukaranej pychy) z prawdziwą symfonią zmysłów, a w przypadku sceny z Arką także z symfonią sztuk: poeta tworzy - na podstawie tego, co "naprawdę" ujrzał w zaświatach - obraz, z którego unosi się śpiew, a w takt muzyki rozwija się taniec i wszystko pozostaje w ruchu. Nasuwa się refleksja, że wzrok jest zmysłem uprzywilejowanym w odbiorze wrażeń wykreowanych w tych obrazach skalnych, przejmującym rolę innych zmysłów; na poziomie stylistycznym daje to efekt niezwykłej synestezji. A ponieważ podczas aktu czytania zawsze tylko za pomocą wzroku następuje percepcja innych wrażeń $^{43}$, w tym konkretnym wypadku można mówić o analogii pomiędzy tym, jak Dante pielgrzym odbiera sztukę Boga i jak czytelnik odbiera sztukę Dantego autora, będącą jej odpowiednikiem poetyckim/słownym.

Poprzez tego typu ekfrazy Dante z jednej strony oddaje cześć Bogu Stwórcy, nie tylko jako autorowi rzeźb żywych i prawdziwych do tego stopnia, że „zawstydzają” naturę, ale także jako autorowi całej rzeczywistości stworzonej, widzialnej i niewidzialnej - tej ostatniej normalnie zakrytej dla oka i intelektu ludzkiego. Z drugiej strony wyjaśnia czytelnikom - poprzez mise en abyme - fenomen własnej

43 Zob. G. Güntert, Canto X, w: Lectura Dantis..., vol. 2: Purgatorio, s. 147. 
sztuki, nadzwyczaj ekfrastycznej i mimetycznej ${ }^{44}$, zdolnej maksymalnie wykorzystać możliwości retoryczne języka poetyckiego, aby tę rzeczywistość przedstawić - od brzydoty duchowej piekła po wysublimowane wizje niebiańskie, od świata materii po świat ducha, posługując się z jednakowym mistrzostwem rymami „szorstkimi i zgrzytliwymi” („rime aspre e chiocce”; Inf. XXXII 1), jak i metaforyką światła i szeroką gamą stylistyczną, porównując to, co pozornie nieporównywalne, wyobrażając to, co niewyobrażalne oraz cały wachlarz namiętności, odczuć, wrażeń, emocji i uczuć. I wzbudzając je w odbiorcach.

Przykład tego czytelnik otrzymuje pod koniec tej samej pieśni X Czyśćca: w pewnym momencie Dante pielgrzym dostrzega z daleka duchy pysznych, skulone pod ciężarem niesionych na barkach głazów, i w pierwszej chwili bierze je za rzeźby skalne. W życiu pyszni częściej kierowali się fałszem niż prawdą, „, na duchowe zaślepienie chorzy” („de la vista e de la mente infermi”; Purg. X 122), dlatego teraz nie wydają się Dantemu żywymi istotami (w. 111-112), lecz kamiennymi figurami, zgiętymi tak, że ich kolana dotykają piersi, podtrzymującymi różne elementy architektoniczne (jakby męską odmianą kariatyd). W refleksji narratora widok takich nieożywionych tworów sztuki musi wywołać współczucie patrzącego:

Come per sostentar solaio o tetto, per mensola talvolta una figura si vede giugner le ginocchia al petto, la qual fa del non ver la vera rancura nascere 'n chi la vede [...].

(Purg. X 130-134)

${ }^{44}$ Jest wiele miejsc w poemacie Dantego, w których technika poetycka przedstawia się jako doskonale mimetyczna w sensie nakreślonym powyżej. Zauważył to jeden z pierwszych dziewiętnastowiecznych komentatorów Komedii, Enrico Mestica (Dante Alighieri, La Commedia, commento di E. Mestica, Firenze 1921-1922, passim), kładąc nacisk na ważność pojęcia visibile parlare dla sztuki Dantego i ukazując, jak ono funkcjonuje w różnych epizodach, poczynając od sceny z Charonem w pieśni III Piekła (82-99). 
[Jak podtrzymując dach lub pułap sieni, z kolanem w piersi, kamienni siłacze

Gną się ciężarem gzymsu przytłoczeni,

Skąd patrzącemu serce się rozpłacze

Przed złudą prawdy [...]].

W tym porównaniu Dante autor nawiązuje już nie do sztuki Boga, która nadaje materii życie, podobnie jak Jego Słowo (najlepszym przykładem jest macierzyństwo Maryi, zapowiedziane, jak wspomnieliśmy, przez archanioła Gabriela na pierwszej płaskorzeźbie). Tutaj jest mowa o sztuce ludzkiej, będącej zawsze tylko fikcją, niekiedy jednak (w dziełach wybitnych) sprawiającą wrażenie prawdy i wywołującą w odbiorcy szczere emocje, przez co prowadzi do przeżyć estetycznych. Można się w tym uogólnieniu doszukać aluzji do sztuki Dantego, która będąc obiektywnie mimetyczną fikcją, w rzeczywistości staje się nośnikiem prawdy i zdolna jest wzbudzić autentyczne uczucia ${ }^{45}$, podobnie jak owe kamienne figury. W ten sposób Alighieri obala już po raz drugi - oskarżenie pochodzenia platońskiego ${ }^{46}$, głoszące oddalenie się wszelkiej twórczości artystycznej od prawdy, to, że jest ona jedynie cieniem cienia. Tym razem czyni to nie w odniesieniu do sztuki Boga (płaskorzeźb na tarasie pysznych), lecz ludzkiej, która - jak jego własna - dostrzega swoje źródło w boskiej „matrycy”47, nie posuwając się jednak do rywalizacji z Bogiem. Poeta daleki jest bowiem od przypisywania jedynie sobie przywileju tworzenia sztuki

45 Byłby to też przykład estetycznego spojrzenia Dantego na sztukę. Za swoisty paradoks można uznać fakt, że postacie wyrzeźbione na tarasie pysznych wydają się jak żywe, a duchy pysznych sprawiają wrażenie kamiennych figur. Paradoks ten staje się mniej paradoksalny, jeżeli się zauważy, że rzeźby są dziełem Boga (i dlatego jest w nich życie), a pyszni na początku drogi ekspiacji mają w sobie jeszcze wiele duchowej martwoty.

46 Zob. Platon, Soph. 235 D. Korzystam z wydania: Plato, Theaetetus, Sophist, Greek with trans. by H.N. Fowler (Loeb Classical Library 123), Cambridge (Mass.) 1921.

47 Zob. Par. XXV 1-2: „'l poema sacro / al quale ha posto mano e cielo e terra” („poemat święty, co doń społem / Ziemia i niebo przykładały dłoni”). 
nie tylko przypominającej boską, ale nawet zdolnej ją przedstawić. Podczas podróży przez Raj, polegającej na stopniowym odkrywaniu Bożego arcydzieła i jego istoty, narrator wypowiada następującą myśl:

Quei che dipinge lì, non ha chi 'l guidi; ma esso guida, e da lui si rammenta quella virtù ch'è forma per li nidi.

(Par. XVIII 109-111)

[Kto tam maluje, nie ma mistrza swego, lecz mistrzem mistrzów jest i zeń wypływa moc, która gniazda tworzy kształt wszelkiego ${ }^{48}$. (przeł. A.K.)

Nie tylko wyrażono tu istotę boskiej sztuki sensu lato, czyli stworzenie czegoś z niczego (creatio ex nihilo) ${ }^{49}$, ale w słowach „ma esso guida” (dosł.: „ale to on prowadzi”) dano jasną wskazówkę, jak należy rozumieć naturę ludzkiej sztuki. Bóg „namalował” $i$ „wyrzeźbił” wszechświat, i jest jego mistrzem mającym w swoim posiadaniu tak zwaną virtus informativa (zdolność nadawania rzeczom formy), stanowiącą archetyp dla wszystkich form, czyli tego, co stanowi istotę każdej stworzonej rzeczy i na niej odciska swoje piętno (termin 'forma' należy oczywiście rozumieć w znaczeniu arystotelesowskim). Dante autor przyznaje niejako, że w Bogu tkwią zalążki każdej potencjalnej twórczości człowieczej. A zatem sztuka, od figuratywnej po poezję, wywodzi swój rodowód od najwyższej mocy twórczej ${ }^{50} \mathrm{i}$ dlatego jest

${ }^{48}$ Sens w. 111: moc, która nadaje formę - w znaczeniu arystotelesowskim stworzeniom jeszcze $w$ stadium embrionalnym.

${ }^{49}$ W innym miejscu Raju (X 7-12), wcześniej cytowanym, oddana została myśl mająca swój rodowód w Biblii, że „sztuka Boga”, czyli akt stworzenia, jest nierozerwalnie związana z miłością Mistrza do „przedmiotu własnej twórczości”.

${ }^{50}$ Twórczość artystyczna zostaje porównana do boskiego dzieła stwarzania świata także w Par. XIII 73-78, gdzie podkreśla się granice ludzkich możliwości: doskonała znajomość technik artystycznych może nie przełożyć się na końcowy rezultat z powodu trudności natury fizycznej: „Se fosse a punto la cera dedutta / e fosse il cielo in sua virtù suprema, / la luce del suggel parrebbe tutta; / ma la natura la dà 
powołana per definitionem do ukazywania prawdy. Co więcej, boski rodowód sztuki wyznacza jedyną właściwą relację pomiędzy twórcą a przedmiotem twórczości, a jest to relacja oparta na miłości, która emanuje na otoczenie. Zniszczenie tych więzów i zastąpienie ich „złą miłością” („mal amor”; Purg. X 2), nakierowaną na siebie, jaka cechowała pysznych, wyrażającą się na przykład nieopanowanym dążeniem do sławy przez sztukę (który to temat nieprzypadkowo poruszany jest w pieśni XI Czyśćca z napotkanym na tarasie pysznych słynnym miniaturzystą z czasów Dantego Oderisim da Gubbio), prowadzi też do zatracenia jej pierwotnego celu - szukania prawdy - i w rezultacie powoduje jej degradację albo nawet upadek.

Starożytna literatura, zwłaszcza Metamorfozy Owidiusza, pełna jest przykładów ludzkiej hybris, rzucającej wyzwanie bogom, między innymi w dziedzinie sztuki, co zawsze kończyło się tragicznie dla człowieka. Komedia kilkakrotnie nawiązuje do takich exemplów: mają one zwykle wymowę metapoetycką ${ }^{51}$, jak aluzja do rywalizacji córek króla tesalskiego Pierosa z muzą Kaliope (Purg. I 7-12) albo satyra Marsjasza z Apollonem (Par. I 19-21) czy Arachne z Ateną: ten ostatni przykład ściśle się wiąże z poruszaną tu tematyką, bowiem pojawia się w niezwykle syntetycznej ekfrazie na tarasie pysznych wśród płaskorzeźb ukazujących ukaraną pychę:

O folle Aragne, sì vedea io te

già mezza ragna, trista in su li stracci

de l'opera che mal per te si fé.

(Purg. XII 43-45)

sempre scema, / similmente operando a l'artista / ch'a l'abito de l'arte ha man che trema” („Gdyby ta miazga była bez poszlaki / I pełnia wpływów szła z niebiosów toni, / W bytach by żadne nie istniały braki. / Ale natura dużo blasku roni, / Tworząc swe dzieło, właśnie jak artysta, / Który zna kunszt swój, lecz jest słabej dłoni”).

${ }^{51}$ Zob. przede wszystkim T. Barolini, Ricreare la creazione divina..., s. 184 i nn.; eadem, Arachne, Argus, and St. John. Transgressive Art in Dante and Ovid, „Mediaevalia" 13 (1987), s. 207-226; P. Royston Macfie, Ovid, Arachne, and the Poetics of Paradise, w: The Poetry of Allusion. Virgil and Ovid in Dante's "Commedia", ed. by R. Jacoff, J.T. Schnapp, Stanford (Calif.) 1991, s. 159-172. 
[O szalona Arachno, widziałem cię na wpół kobietą i na wpół pająkiem, nieszczęsną, zawieszoną na podartej tkaninie dzieła, które przywiodło cię do zguby].

(przeł. M.M.-S.)

O tym, że Dante nadał niezwykłą rangę właśnie temu exemplum świadczy fakt, że zajmuje ono centralną pozycję wśród trzynastu przykładów tworzących, o czym była już mowa, bardzo kunsztowny retorycznie (i nacechowany symbolicznie) układ. Jednak i w $\mathrm{Me-}$ tamorfozach Owidiusza ta opowieść uzyskuje szczególną rangę ze względu na wyjątkowy artyzm sztuki dziewczyny z Meonii, niezwykłą mimetyczność jej obrazów „malowanych igłą” („pingebat acu”; VI 23), zatarcie granic pomiędzy sztuką i życiem:

Maeonis elusam designat imagine tauri

Europam; verum taurum, freta vera putares;

ipsa videbatur terras spectare relictas

et comites clamare suas tactumque vereri

adsilientis aquae timidasque reducere plantas ${ }^{52}$.

(Met. VI 103-107)

[Arachne wyobraża porwanie Europy przez Jowisza, który przybrał postać byka. Byk jest jak żywy, woda - jak prawdziwa. Europa ogląda się na brzeg pozostawiony, przyzywa przyjaciółki, boi się dotknięcia fali, cofa trwożnie stopy $]^{53}$.

Co więcej, rzymski poeta nadaje nie wprost całemu epizodowi wymiar metapoetycki ${ }^{54}$ (podobnie jak potem Dante) i w tym odniesieniu jej sztuki do własnej można się doszukiwać szczególnego powodu zainteresowania Owidiusza historią Arachne, w której także dzieło

52 Metamorfozy w oryginale cytuję (tu i dalej) z wydania: Ovidio, Metamorfosi, a cura di N. Scivoletto, Torino 2009.

${ }^{53}$ Metamorfozy w przekładzie cytuję (tu i dalej) z wydania: Owidiusz, Metamorfozy, przeł. A. Kamieńska, S. Stabryła, Wrocław 1995.

${ }_{54}$ Zob. na przykład E. Winsor Leach, Ekphrasis and the Theme of Artistic Failure in Ovid's "Metamorphoses”, „Ramus” 3 (1974), s. 102-142. 
Ateny, równie doskonałe, cechuje podobna metaliteracka funkcja. Nie tylko ze względu na formę, na wyjątkową wirtuozerię słowną i efekt „visibile parlare”, lecz także od strony tematycznej: istotnie oba dzieła aluzyjnie nawiązują do tematyki Metamorfoz (o czym świadczą błyskotliwe ekfrazy) z ich wiodącym tematem przemiany ludzi i bogów, są jakby ich miniaturową wersją, a zatem i tu - podobnie jak potem u Dantego - można mówić o mise en abyme. Każdy z obrazów „malowanych igłą” ukazuje jednak prawdę połowiczną: Atena przedstawia bogów w ich pełnym majestacie, nawiązując do szlachetnej rywalizacji własnej z Posejdonem o nadanie imienia przyszłym Atenom w obecności wszystkich bogów olimpijskich, a w czterech rogach tkaniny ukazuje karę - poprzez przemianę - wymierzoną śmiertelnikom, którzy ośmielili się z nimi rywalizować o pierwszeństwo (jest to ostrzeżenie dla żądnej sławy prządki lidyjskiej). Z kolei Arachne przedstawia bogów w bardzo negatywnym świetle, obnażając ich występki, to, jak używają swojej potęgi do oszukiwania i wykorzystywania ludzi, głównie do uwodzenia kobiet, kryjąc się pod postaciami różnych zwierząa ${ }^{55}$. Atena karze ją też i za to. Te dwie półprawdy o bogach uzupełniają się w dziele Owidiusza, choć przeważa punkt widzenia Arachne. Czyżby rzymski wirtuoz słowa chciał w jej osobie ostrzec - nie bez dozy ironii - siebie samego przed gniewem bogów? Z drugiej strony to ich właśnie w proemium wskazał jako właściwych autorów przemian i pomocników w realizacji twórczego zamysłu i prosił o natchnienie, zręcznie wykorzystując topos modestiae ${ }^{56}$. Był świadomy artyzmu mimetycznego własnej poezji, ale też (przynajmniej taka jest intentio operis, tak istotna w literaturze

55 Zob. Owidiusz, Met. VI 103-128.

56 Zob. Owidiusz, Met. I 1-4: „In nova fert animus mutatas dicere formas / corpora: di, coeptis (nam vos mutastis et illas) / adspirate meis primaque ab origine mundi / ad mea perpetuum deducite tempora carmen” („Opowiem, jak się w nowe kształty przemieniały ciała. Natchnijcie mnie, bogowie, bo za waszą sprawą działy się te przemiany, a snujcie pieśń odwieczną od początku świata do naszych czasów"). 
średniowiecznej) ryzyka, jakie się z tym wiąże, zwłaszcza wtedy, gdy przybiera ona ton arachnejski ${ }^{57}$.

Dante, który w wielu innych miejscach Komedii wprost lub tylko aluzyjnie krytykuje relację pomiędzy bogami pogańskimi i ludźmi, przebijającą aż nazbyt wyraziście z kart antycznej epiki, zwłaszcza z Metamorfoz, tu jednak, w zgodzie z Owidiuszem ${ }^{58}$, ogniskuje swoją uwagę na winie Arachne, na żałosnych skutkach pełnego pychy negowania boskiego pierwiastka w twórczym natchnieniu, nazywając ją folle, który to epitet oznacza u Dantego zawsze czyn nacechowany hybris ${ }^{59}$. Przykład nieszczęsnej artystki, wyrzeźbiony „ręką" samego Boga, jest dlań przestrogą, mimo współczucia jakie dlań odczuwa, przed przypisywaniem sobie i tylko sobie talentu prowadzącego do zatarcia granic pomiędzy sztuką i życiem. Wpisuje się on w szerszy dyskurs Alighieriego o sztuce, jej istocie, pochodzeniu, jej naturalnym dążeniu do odkrywania misterium życia i śmierci.

${ }^{57}$ Zob. na przykład E. Winsor Leach, Ekphrasis and the Theme of Artistic Failure..., s. 117. Za identyfikowaniem się Owidiusza z Arachne opowiada się zdecydowanie William Anderson w swojej recenzji książki Brooksa Otisa Ovid as an Epic Poet, „American Journal of Philology” 89 (1968), s. 93-104; zob. także L. Barkan, The Gods Made Flesh: Metamorphosis and the Pursuit of Paganism, New Haven (Conn.) 1986, s. 1-4.

${ }^{58}$ Zob. Owidiusz, Met. VI 23-24: „pingebat acu: scires a Pallade doctam. / Quod tamen ipsa negat” („Igłą maluje czary, myślałbyś patrząc, że uczyła ją Pallada. Lecz ona temu przeczy"). Owidiusz mocno podkreśla cierpliwość Ateny i rady, jakie pod postacią staruszki daje śmiertelniczce, by uznała, iż nie tylko sobie zawdzięcza talent, dzięki któremu stała się sławna w całej Lidii, zob. VI 30-33: „Consilium ne sperne meum. Tibi fama petatur / inter mortales faciendae maxima lanae: / cede deae veniamque tuis, temeraria, dictis / supplice voce roga: veniam dabit illa roganti" („Nie gardź moją radą: ciesz się sławą najlepszej tkaczki pośród ludzi. Ustąp bogini nieśmiertelnej, proś pokornie, by ci zuchwałe słowa wybaczyła. Kto prosi o łaskę, otrzyma").

${ }_{59}$ Zob. U. Bosco, Dante vicino, Caltanisetta-Roma 1966, s. 61. 


\section{Bibliografia}

Anderson W., [recenzja książki B. Otisa Ovid as an Epic Poet], „American Journal of Philology" 89 (1968), s. 93-104.

Aristotle, Physics, Books 1-4, Greek with trans. by P.H. Wicksteed, F.M. Cornford (Loeb Classical Library 228), Cambridge (Mass.) 1957.

Arystoteles, Etyka nikomachejska, przeł., oprac. i wstęp D. Gromska, Warszawa 1982.

Arystoteles, Metafizyka, przeł., wstęp, koment. i skorowidz K. Leśniak, Warszawa 1983.

Les Auctoritates Aristotelis. Un florilège médiéval. Étude historique et édition critique, éd. par J. Hamesse, Louvain 1974.

Barański Z.G., Canto XXV, w: Lectura Dantis Turicensis, a cura di G. Güntert, M. Picone, t. 2: Purgatorio, Firenze 2001, s. 389-406.

Barański Z.G., Notes on the Genesis of Dante's "Commedia". "'lpoema sacro [...] che m'ha fatto per molti anni macro", „Italiana” 9 (2000), s. 58-81.

Barkan L., The Gods Made Flesh. Metamorphosis and the Pursuit of Paganism, New Haven (Conn.) 1986.

Barolini T., Arachne, Argus, and St. John. Transgressive Art in Dante and Ovid, „Mediaevalia” 13 (1987), s. 207-226.

Barolini T., Dante's Poets. Textuality and Truth in the "Comedy", Princeton (N.Y.) 1984.

Barolini T., Ricreare la creazione divina: l'arte aracnea nella cornice dei superbi, w: eadem, La "Commedia” senza Dio. Dante e la creazione di una realtà virtuale, trad. it. R. Antognini, Milano 2003, s. 173-198.

Bartuschat J., "Non pur Policteto, ma la natura». Perfezione dell'arte e perfezione della natura in Dante e Boccaccio, w: Studi sul canone letterario del Trecento per Michelangelo Picone, a cura di J. Bartuschat, L. Rossi, Ravenna 2003, s. 79-98.

Boitani P., The Sibyl's Leaves. A Study of “Paradiso” XXXIII, „Dante Studies” 96 (1978), s. 83-126.

Bosco U., Dante vicino, Caltanisetta-Roma 1966.

Curtius R., Literatura europejska i łacińskie średniowiecze, przeł. i oprac. A. Borowski, Kraków 1997, s. 576-578.

Dante Alighieri, Boska Komedia, przeł. E. Porębowicz, oprac. M. Maślanka-Soro, Kraków 2009.

Dante Alighieri, Commedia, a cura di A.E. Quaglio, E. Pasquini, t. 2: Purgatorio, Milano $2010^{14}$.

Dante Alighieri, Inferno, revisione del testo e commento di G. Inglese, Roma 2007.

Dante Alighieri, La Commedia, commento di E. Mestica, Firenze 1921-1922.

Dante Alighieri, La Commedia, vol. 1-3 (Inferno, Purgatorio, Paradiso), con il commento di R. Hollander, trad. a cura di S. Marchesi, Firenze 2011.

Dante Alighieri, Monarchia, introduzione di G. Petrocchi, a cura di M. Pizzica, Milano 1988.

Dante Alighieri, Raj. Boskiej komedii część trzecia, przeł. A. Kuciak, Poznań 2004. 
De Bruyne E., Études d'esthétique médiévale, t. 3, Bruges 1946.

Delcorno C., Dante e l'«Exemplum» medievale, „Lettere italiane” 35 (1983), no 1, s. 3-28.

Faedo L., L'impronta delle parole. Due momenti della pittura di ricostruzione, w: Memoria dell'antico nell'arte italiana, vol. 2, a cura di S. Settis, Torino 1985, s. 3-42.

Guido da Pisa, Expositiones et Glose super Comediam Dantis, ed. by V. Cioffari, Albany (N.Y.) 1974.

Güntert G., Canto X, w: Lectura Dantis Turicensis, a cura di G. Güntert, M. Picone, vol. 2: Purgatorio, Firenze 2001, s. 139-155.

Güntert G., Canto XXXIII, w: Lectura Dantis Turicensis, a cura di G. Güntert, M. Picone, vol. 3: Paradiso, Firenz 2002, s. 505-518.

Hollander J., The Gazer's Spirit. Poems Speaking to Silent Works of Art, Chicago 1995. Hollander R., Il Virgilio dantesco: tragedia nella "Commedia", Firenze 1983, s. 145-154. Horacy, Sztuka poetycka, w: idem, Gawędy, Listy, Sztuka poetycka, oprac. O. Jurewicz (Dzieła Wszystkie, t. 2), Wrocław 1988, s. 420-469.

Hugo de s. Victore, Eruditionis didascalicae liber septimus, w: idem, Opera omnia, t. 2 (Patrologiae Cursus Completus. Series Latina, ed. J.-P. Migne, t. 176), Parisiis 1854. Iannucci A.A., Dante: poeta o profeta?, w: "Per correr miglior acque...”. Bilanci e prospettive degli studi danteschi alle soglie del nuovo millennio. Atti del Convegno di Verona-Ravenna (25-29 ottobre 1999), vol. 1, Roma 2001, s. 93-114.

Ledda G., La danza e il canto dell' "umile salmista»: David nella "Commedia" di Dante, w: Les figures de David à la Renaissance, éd. par E. Boillet, S. Cavicchioli, P.-A. Mellet, Genève 2015, s. 225-246.

Maślanka-Soro M., Antyczna tradycja epicka u Dantego, Kraków 2015.

Nardi B., Dante profeta, w: idem, Dante e la cultura medievale, nuova ed. a cura di P. Mazzantini, introduzione T. Gregory, Roma-Bari 1983, s. 265-326.

Osculati R., La profezia nel pensiero di Dante, w: Il pensiero filosofico e teologico di Dante Alighieri, a cura di A. Ghisalberti, Milano 2001, s. 39-57.

Ovidio, Metamorfosi, a cura di N. Scivoletto, Torino 2009.

Owidiusz, Metamorfozy, przeł. A. Kamieńska, S. Stabryła, Wrocław 1995.

Placella A., Profetismo e archetipo del 'puer' in Dante tra Isaia, Virgilio e Paolo, Roma 2017.

Placella A., "Vidi cose che ridire / né sa né può chi di là sù discende». Dante poeta-teologo e il modello paolino di visione e profezia, „Critica letteraria” 45 (2017), no 4 , s. 641-666.

Plato, Theaetetus, Sophist, Greek with trans. by H.N. Fowler (Loeb Classical Library 123), Cambridge (Mass.) 1921.

Plato, Timaeus, Critias, Cleitophon, Menexenus, Epistles, Greek with trans. by R.G. Bury (Loeb Classical Library 234), Cambridge (Mass.) 1989.

Reale G., Storia della filosofia antica, vol. 5, Milano 1989.

Royston Macfie P., Ovid, Arachne, and the Poetics of Paradise, w: The Poetry of Allusion. Virgil and Ovid in Dante's "Commedia", ed. by R. Jacoff, J.T. Schnapp, Stanford (Calif.) 1991, s. 159-172. 
Salsano F., Arte, w: Enciclopedia Dantesca, vol. 5, Milano 2005, s. 611-615.

Tomasz z Akwinu, Summa theologiae, www.corpusthomisticum.org/sth0000.html (dostęp: 2.06.2019).

Vescovo P., Ecfrasi con spettatore (Dante, "Purgatorio”, X-XVII), „Lettere italiane” 45 (1993), no 3, s. 335-360.

Winsor Leach E., Ekphrasis and the Theme of Artistic Failure in Ovid's "Metamorphoses”, „Ramus” 3 (1974), s. 102-142. 